\title{
Cybertherapy in Medicine - Experience at the Universidad Panamericana, IMSS and ISSSTE Mexico
}

José Luis Mosso, Gregorio T. Obrador, Brenda Wiederhold, Mark Wiederhold, Verónica Lara and Amador Santander

Additional information is available at the end of the chapter

http://dx.doi.org/10.5772/52349

\section{Introduction}

There are many reports of Virtual Reality analysis and clinical applications in Medicine since the end of the last century for many authors. In trauma head injuries [1], during chemotherapy in children [2], in burn wound care [3,4,5], lumbar puncture [6,], breast cancer [7], vein puncture [8], pain distraction [9,10,11,12], dental pain control [13], leg ulcer relief [14], night vision technology with robot control to treat bourn injuries using robot-like arm mounted VR goggles [15]. The first case reports related with VR and medical invasive procedures and surgery in hospitals was in 2004 with our group, beginning with upper gastrointestinal endoscopies and so on, until introduce VR in postoperative care unit of cardiac surgery $[16,17]$.

Pain and anxiety in outpatients and inpatients is a regular symptom in hospitals. For pain are available medications and for anxiety also. Patients in; in-rooms, operating rooms and another different places, get treatments with medical and surgical procedures, and pain and anxiety are the meanly symptom. In this project we try to demonstrate that virtual reality is a complementary tool to reduce pain and anxiety in hospitals during medical procedures including surgical procedures. There are a lot reason and justifications to use VR in hospitals, as follows. Neonatology (0-28 days old), there are newborns staying in unit cares since few days, weeks even months, growing without contact with the external world. The visit unit care is limited to parents in few hours a day. The psychological impact in growth and development in childhood is so hard, where neuro stimulation in a closed environment is a good alternative. In Infants (lower and higher infants) VR have been a good resource to reduce pain and anxiety in oncology. Hunter Hoffman has demonstrated in the benefits of 
VR during medical rehabilitation in burned childhood. In postoperative cardiac surgery unit care, patients stay 3 days in different critical care units depending of their progress. In these units they stay under the influence of sedative drugs receiving treatments by vein catheters, gastric tube, etc. Their recovery is on beds with different degrees of limited position and the breathing relief is on bed also. In ambulatory surgery (General surgery, endoscopic surgery, urology, dermatology, Orthopedic, angiology, pediatric surgery, obstetrics), patients are awake, minutes, even hours awake during surgical procedures doing nothing in a same position on a surgical table. In the recovery they stay hours waiting for go home or to be hospitalized. Special group of ambulatory surgery, surgeon used night vision technology while patients navigate in VR environment. At the school of medicine from Universidad Panamericana we used night vision on animal models before the application on humans. Gynecology and obstetrics. Women during colposcopy are awake while gynecologist applies local anesthesia into the cervix to perform cervical conization with diathermal loop. The anxiety is present in a same gynecological position. Gastrointestinal endoscopy. Under local anesthesia, neurovegative response is present during and after each upper gastrointestinal exploration of esophagus, stomach and duodenum. Patients present plenty of saliva associated with shortness of. Labor Room. Pregnant patients without complications expected hours to complete cervical dilation in labor room to go into delivery room or operating room. During uterus contractions they increase their respiratory rate. Pediatric. Scholar children stay on bed many days in recovery. In their stay they distract with games and in some times with a TV only. Epidural and Spinal block in anesthesia. This is a relative fast procedure compared with the previous groups where patient in the fetal position they expect catheter installation in their back, place where they can't see anything and anxiety is present despite local infiltration.

\section{Methodology}

The conditions to perform the following project are. Consent informed, full consciousness; agree to participate in the project; completeness vision, controlled cardiovascular and respiratory disease. Patients were afíliate at Instituto Mexicano del Seguro Social (IMSS) and Instituto de Seguridad y Servicios Sociales para los Trabajadores del Estado, (ISSSTE). In case of newborns, parents signed consent informed.

Technique. Before each procedure, nurse measured blood pressure, heart rate, breath rate (In the case of patients in unit cares, we considered arterial blood gases). Physician asks patients about his-her feelings (Anxiety) in a scale of 0 to 10 (where 0 is no pain and 10 is high pain). Physician installed the following equipment also: Laptop with 3 virtual scenarios (Enchanted forest, cliff final, icy city see figure 2) and connected to a vision goggles eMagin. When we used smart phones (Nokia N95 and iPhone G3) and PSP2 we used a mp3 video with a green valley scenario connected to goggles. Once set up the equipment, it was installed in the patient's head. Physician begins the procedure and in the middle of the procedure, nurse measured vital signs again and physician repeats the same question about the feelings (Anxiety and pain). Head Mounted display is removed of the head's patient at 
the end of each procedure and 15 minutes after, nurse made the third measure of vital signs and physician asks the feelings of the patient again. In the case of Night Vision Goggles (NV) for ambulatory surgery for total darkness was necessary to perform open surgery on rabbits at the school of Medicine at the Universidad Panamericana in 9 rabbits under general anesthesia before to make ambulatory surgeries on humans. NV equipment needs a scrub nurse to hold all equipment on the head of surgeon and first assistant after dressing with sterile clothing. Cables were connected beside the surgical table. Diagnosis of surgery group: big lipomas on head, arms, legs or abdomen, non complicated inguinal and umbilical hernias. Complicated and non complicated postoperative hernias in the abdominal wall. For Laparoscopic group: non acute cholecystitis, and inguinal hernias. With night vision technology group: big lipomas on arms, legs and non complicated inguinal hernia. Diagnosis for postoperative care unit of cardiac surgery: aortic and mitral valves rechange and coronary revascularization. Colposcopy group: cervicitis and premalignant lesions in cervix. Neonatology group: premature newborns in recovery with more than 5 days to 2 months of hospitalizations with multiple diagnosis such as necrotizing enterocolitis, sepsis, respiratory disorders. In the kidney transplantation only one patient in the recovery used VR. In obstetrics, patients with 48 weeks of pregnant with 5 to 10 of cervical dilation participate with normal fetus in labor room where epidural or spinal block were installed and we follow the same patients to the delivery room and to the operating rooms. In the group of endoscopy, diagnosis was hiatal hernia, peptic disease and colon disorder.

\section{Results}

The comparative measure of pain were made before, during and after each procedure in all groups using Virtual Reality and the control group, except in patients without any medical procedure such as the group of care unit of cardiac surgery and neonatology. The statistical method to measure pain used was the mean into the scale of 0 to 10 (Cero is no pain and 10 is high level of pain). We present statistical results in the 3 representative groups where pain and anxiety are high such as colposcopy (see table 3), ambulatory surgery (see table 4) and postoperative care unit of cardiac surgery (See table 5). With the results of these groups we can appreciate the possibilities to use this technique in another groups into the hospitals because we have been tested VR in a group seriously ills in critical care units in cardiac surgery and manipulations of tissues including abdominal cavity in ambulatory surgery group. In table 1 we measured mean pain (see figure 1 ) between before to during the procedure and between before to after (see table 1). In the colposcopy group that used VR the mean pain before the procedure was 7.5 and during was 5.35 with a difference of 2.15 that correspond of $28.66 \%$ of reduction of pain. In the group of colposcopy that didn't use VR the mean pain before was 6.43 and during 6.78 with an increase and difference of 0.35 that correspond of $5.44 \%$ of increasing of pain, in the same group considering mean pain before of 6.43 and 4.83 after, the difference was 1.6 that correspond of $24.88 \%$ of reduction of pain. In all groups we demonstrated an important reduction of pain using VR during medical or surgical procedures (see table 2). In care unit of cardiac surgery group the mean 
pain before were 8 and after 30 was 3.64 with a difference of 4.36 that correspond to $54.5 \%$ of reduction of pain-anxiety (See table 2). In the group of surgery there were a mean of pain before of 5.7 and during the procedure 3.93 with a difference of 1.8 that correspond of 31.41 $\%$ of reduction on pain. Considering the mean pain before of 5.73 and 2.09 after, there is a difference of 3.64 that correspond to $63 \%$ of reduction of pain. In the group of surgery that didn't use VR the pain mean were 5.57 before and during 5.19 with a difference of 0.48 that correspond to $6.8 \%$ of reduction, and considering the mean pain before of 5.57 and 3.52 after there is a difference of 2.05 that correspond to $36.80 \%$ of reduction of pain. With these results we can appreciate the impact of distraction of VR to reduce anxiety and subsequently visceral and somatic pain in the case of surgery with regional anesthesia well placed.

$$
\bar{x}=\frac{1}{n} \sum_{i=1}^{n} a_{i}=\frac{a_{1}+a_{2}+\cdots+a_{n}}{n}
$$

Figure 1. Mean equation to obtain results

\begin{tabular}{|l|l|l|l|l|l|}
\hline $\begin{array}{l}\text { MEAN of } \\
\text { pain and } \\
\text { anxiety }\end{array}$ & $\begin{array}{l}\text { Colposcopy } \\
\text { with HMD }\end{array}$ & $\begin{array}{l}\text { Colposcopy no } \\
\text { HMD }\end{array}$ & $\begin{array}{l}\text { Critical care } \\
\text { unit of cardiac } \\
\text { surgery }\end{array}$ & $\begin{array}{l}\text { Ambulatory } \\
\text { surgery. with } \\
\text { HMD }\end{array}$ & $\begin{array}{l}\text { Ambulatory } \\
\text { surgery. No } \\
\text { HMD }\end{array}$ \\
\hline Before & 7.5 & 6.43 & 8 & 5.73 & 5.57 \\
\hline During & 5.35 & 6.78 & & 3.93 & 5.19 \\
\hline After & 2.7 & 4.83 & 3.64 & 2.09 & 3.52 \\
\hline
\end{tabular}

Table 1. Comparative measure of mean pain before, during and after each procedure in 3 representative groups. Pain scale used 0-10. (0 means no pain and 10 high pain).

\begin{tabular}{|l|l|l|l|l|l|}
\hline $\begin{array}{l}\text { \% of pain and } \\
\text { anxiety } \\
\text { Reduction }\end{array}$ & $\begin{array}{l}\text { Colposcopy } \\
\text { with HMD }\end{array}$ & $\begin{array}{l}\text { Colposcopy no } \\
\text { HMD }\end{array}$ & $\begin{array}{l}\text { Critical } \\
\text { care unit } \\
\text { of cardiac } \\
\text { surgery }\end{array}$ & $\begin{array}{l}\text { Ambulatory } \\
\text { surgery. with } \\
\text { HMD }\end{array}$ & $\begin{array}{l}\text { Ambulatory } \\
\text { surgery. No } \\
\text { HMD }\end{array}$ \\
\hline Before - during & $28.66 \%$ & $5.44 \%$ & $54.5 \%$ & $31.41 \%$ & $6.8 \%$ \\
\hline Before - after & $64 \%$ & $24.88 \%$ & & $63 \%$ & $36.80 \%$ \\
\hline
\end{tabular}

Table 2. Pain and anxiety percentage reduction, between before and during procedures. Pain scale used 0-10. (0 means no pain and 10 higher pain).

As a result of patient selection, we suggest the following general criteria to use VR in Medicine: 1.- Patients with voluntary participation, and signed authorization with written consent informed, (Patients under 18 years of age need written informed consent from parents), 2.- Medical control of cardiovascular, respiratory and neurological diseases, and 3.full consciousness. (See figures 2 to 12 ) 

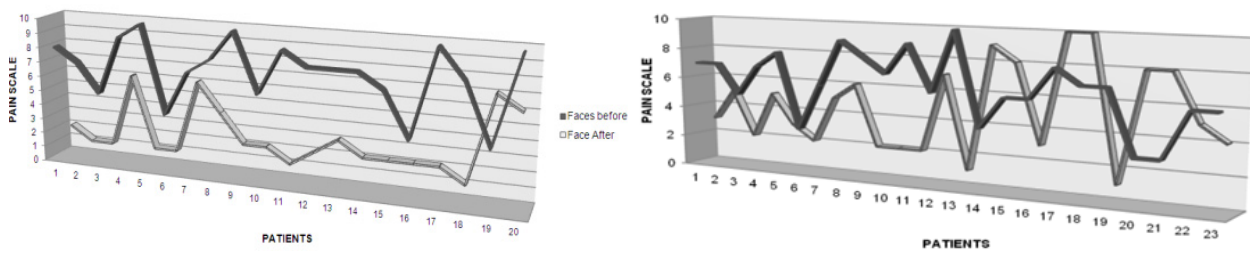

Table 3. Colposcopy. Group with VR (left) and control group (right)
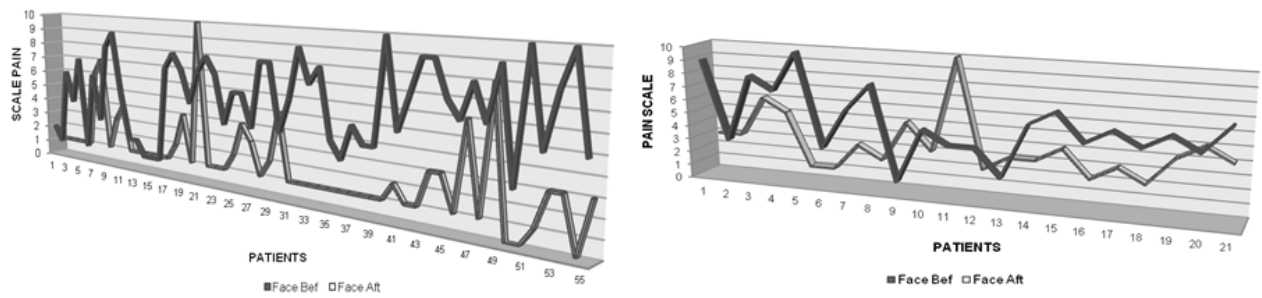

Table 4. Ambulatory surgery. Group with VR (left) and control group (right)

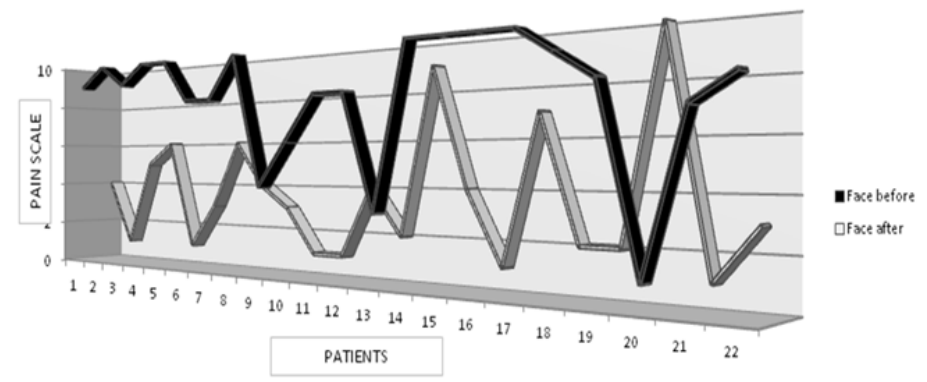

Table 5. Postoperative Care Unit of cardiac surgery

Medical complications. 2 patients of 22 in care unit of cardiac surgery group presented cardiac arrhythmias during the virtual navigation due to the slow effort on the bed, the treatment was the immediately disruption of VR exposure with total recovery. In ambulatory surgery group with local anesthesia, 2 patients presented nausea and vertigoes using VR and after 30 minutes patients become tired to carry goggles on their heads in the same position, for this reason we used a projector to display a screen in the roof of the operating room. In the subgroup of endoscopic surgery under regional anesthesia, 3 patients of 5, presented chest pain secondary of neumoperitoneum and it was necessary convert regional anesthesia to general (For this reason we don't suggest VR for endoscopic surgery under regional anesthesia). (See table 6). 


\begin{tabular}{|c|c|c|}
\hline Area & Cases & Complications \\
\hline $\begin{array}{l}\text { Care unit of } \\
\text { cardiac surgery }\end{array}$ & Care Unit & 2 patients presented arrhythmias. \\
\hline Surgery & $\begin{array}{l}\text { General } \\
\text { Surgery } \\
\text { Endoscopic } \\
\text { surgery } \\
\text { Urology } \\
\text { Angiology } \\
\text { Dermatology } \\
\text { Orthopedic } \\
\text { Angiology } \\
\text { Pediatric } \\
\text { Obstetric } \\
\end{array}$ & $\begin{array}{l}2 \text { patients presented nausea and vertigoes, another one } \\
\text { presented pain in peritoneum manipulation. } \\
3 \text { patients presented chest pain and difficulty breathing } \\
\text { None } \\
\text { None } \\
\text { None } \\
\text { None } \\
\text { None } \\
\text { None } \\
\text { None } \\
\text { None }\end{array}$ \\
\hline Anesthesia & $\begin{array}{l}\text { Epidural/spinal } \\
\text { block }\end{array}$ & None \\
\hline Obstetric & $\begin{array}{l}\text { Labour room } \\
\text { Childbirth } \\
\text { room } \\
\end{array}$ & $\begin{array}{l}\text { None } \\
\text { None }\end{array}$ \\
\hline Endoscopy & $\begin{array}{l}\text { Upper } \\
\text { Endoscopy } \\
\text { Colonoscopy } \\
\end{array}$ & $\begin{array}{l}\text { None } \\
\text { None }\end{array}$ \\
\hline
\end{tabular}

Table 6. Complications

Technical limitations. In ambulatory surgery, patients need to move their hands to get more distraction; but they hands tied to the table to avoid contamination and in the other hand they become tired with the goggles on their heads and after 45 minutes they prefer change the projection of the scenario to the roof of the operating room. With NV we found limitation for surgeon's motions for the cables connected to the wall beside the table one meter away. We had distorted vision for the glasses used, and the vision was in black and white color. The surgical time was small longer than conventional surgical time. In neonatology group, newborns present 5 to 8 seconds of attention for VR. It was difficult to evaluate the benefits of this technology, this is the reason we don't present statistical results. We suggest using another kind of device of VR to interact with these patients who have limited vision.

\section{Conclusions}

We found differences results according with age, gender, procedures, culture, origin of regions, diagnosis, prognosis, but in all groups we found reduction of pain and anxiety, one more than others, except the subgroup of endoscopic surgery, the only one we don't suggest use VR. . The group that enjoyed better the virtual scenarios was patients between 5 to 14 
years of age in pediatric group. The older patients demonstrated curiosity of new technology that had in their hands.

There where patients exposed with Virtual Reality in different conditions like age, sex, medical procedures and different physicians but all results show us reduction of anxiety and pain. The answers were different in each group because pathways of pain involved are two, somatic and visceral. Tissues and organs manipulated were different, for instance: Skin, fat, muscles, fascias, peritoneum, cervix, uterus, peritoneum, spine's dura, ligaments, small and medium vessels, gallbladder, omentum, visceral peritoneum, parietal peritoneum, esophagus, stomach and colon's mucous. On the other hand, Patient's psyche played an important role for anxiety and pain. All patients required medications for local and regional anesthesia such as analgesics, sedatives, in different dosages. The high level of pain we saw in all groups of patients was those who underwent endoscopic surgery.

In the beginning of our experience, we used a Spider HMD game to distract patients under upper GI endoscopy in 2004. Thanks of these results we improved the devices introducing Virtual reality scenarios and a HMD developed by Brenda and Mark Wiederhold from the Virtual Reality Medical center from San Diego CA. Clinical applications were done at the Instituto de Seguridad y Servicios Sociales para los Trabajadores del Estado I.S.S.S.T.E. and at the Instituto Mexicano del Seguro Social IMSS, Public Health Centers in Mexico City. There were big and small groups because the results from critical care unit of cardiac surgery and ambulatory surgery allow us to conclude the usefulness of virtual reality to reduce pain and anxiety in inpatients without minimal complications and permit us to limit virtual applications in all areas of Medicine. If patients in critical care unit presented no more than 2 complications and in surgery we consider absolutely contraindicated in endoscopic surgery is obvious to use virtual reality without major risk in the rest of areas of medicine if we follow the absolute indications.

Virtual reality is a not invasive method, easy to use, easy to install and easy to carry and each day new generations of technology are lighter, smaller such as smartphones, PSP 2, iPADs that permit more interaction with users using friendly feedbacks such as tracking (Kinect), 3D images permit more immersion with Interactive screens that could be considered in future works because U screens, virtual cubes and cave could be an option for patients because these screens have demonstrated the utility in rehabilitation for the big space for body motions and for the stereoscopic immersion.

The best advantage for the healthcare institutions we found in the group for ambulatory surgery was to reduce the half of dosage of medication of fentanyl, and midazolam, and in many cases we avoid totally these medications in the intraoperative. This advantage represent an important saving for institutions always considering and appropriate selection of patients with absence of cardiovascular and respiratory disease that could permit physician works without concerns during procedures. With these results we can give the following advantages as: reduction of medication (Analgesic and in several cases, drugs to reduce anxiety as fentanyl and mydazolam), bed days and specially increase the wellbeing of patients. There were small groups of one or two patients that should increase the number 
of cases to get reliable results, however theirs results are a clear indicator of benefits of virtual reality. We didn't consider more areas of medicine, but we involve representative as surgical and clinical areas and both sex, males and females and different ages, newborns and adults. Technology developments permit use small device such as mobile phones to connect to head mounted display instead of laptops; they facilitate the handling of the virtual scenarios. 3D scenarios will permit more immersion in patients (see table 7). Display scenario on the wall is an option for navigations instead to use HMD which can be tiring for patients in prolonged time. Virtual reality is useful in hospital and we consider that in the future, virtual rooms could be integrated inside services, operating rooms, and waiting rooms.

\begin{tabular}{|c|c|c|c|c|c|c|}
\hline $\begin{array}{l}\text { Medicine } \\
\text { Apps }\end{array}$ & $\begin{array}{l}\text { Interface } \\
\text { used }\end{array}$ & $\begin{array}{l}\text { Virtual } \\
\text { scenario }\end{array}$ & Area & Cases & $\begin{array}{l}\text { Control } \\
\text { group }\end{array}$ & $\begin{array}{l}\text { Patients } \\
\text { participants }\end{array}$ \\
\hline $\begin{array}{l}\text { Ambulatory } \\
\text { Surgery }\end{array}$ & Laptop & $\begin{array}{l}\text { Enchanted } \\
\text { forest }\end{array}$ & Surgery & 53 & 31 & 84 \\
\hline $\begin{array}{l}\text { Ambulatory } \\
\text { Surgery }\end{array}$ & $\begin{array}{l}\text { Laptop \& } \\
\text { Night vision }\end{array}$ & $\begin{array}{l}\text { Enchanted } \\
\text { forest }\end{array}$ & Surgery & 5 & 0 & 5 \\
\hline $\begin{array}{l}\text { Ambulatory } \\
\text { Surgery }\end{array}$ & Nokia & $\begin{array}{l}\text { Green valley } \\
\text { video }\end{array}$ & Surgery & 23 & 0 & 23 \\
\hline $\begin{array}{l}\text { Ambulatory } \\
\text { Surgery }\end{array}$ & PSP2 & $\begin{array}{l}\text { Green valley } \\
\text { video }\end{array}$ & Surgery & 24 & 0 & 24 \\
\hline $\begin{array}{l}\text { Ambulatory } \\
\text { Surgery }\end{array}$ & X BOX & Video & Surgery & 2 & 0 & 2 \\
\hline $\begin{array}{l}\text { Ambulatory } \\
\text { Surgery }\end{array}$ & iPhone G3 & $\begin{array}{l}\text { Green valley } \\
\text { video }\end{array}$ & Surgery & 2 & 0 & 2 \\
\hline $\begin{array}{l}\text { Pediatric } \\
\text { surgery }\end{array}$ & PSP2 & $\begin{array}{l}\text { Green valley } \\
\text { video }\end{array}$ & Pediatric surgery & 1 & 0 & 1 \\
\hline $\begin{array}{l}\text { Recovery } \\
\text { surgery }\end{array}$ & Laptop & $\begin{array}{l}\text { Enchanted } \\
\text { forest }\end{array}$ & $\begin{array}{l}\text { Kidney } \\
\text { transplantation }\end{array}$ & 1 & 0 & 1 \\
\hline $\begin{array}{l}\text { Surgical } \\
\text { cleaning }\end{array}$ & Laptop & $\begin{array}{l}\text { Enchanted } \\
\text { forest }\end{array}$ & $\begin{array}{l}\text { Surgery- } \\
\text { Infectology }\end{array}$ & 11 & 10 & 21 \\
\hline $\begin{array}{l}\text { Epidural } \\
\text { blockage }\end{array}$ & Laptop & $\begin{array}{l}\text { Enchanted } \\
\text { forest }\end{array}$ & Anesthesia & 4 & 3 & 7 \\
\hline Labor room & Laptop & $\begin{array}{l}\text { Enchanted } \\
\text { forest }\end{array}$ & Obstetric & & & \\
\hline Cesarean & Laptop & $\begin{array}{l}\text { Enchanted } \\
\text { forest }\end{array}$ & Obstetric & 1 & 1 & 2 \\
\hline Delivery Room & Laptop & $\begin{array}{l}\text { Enchanted } \\
\text { forest }\end{array}$ & Obstetric & 1 & 2 & 3 \\
\hline $\begin{array}{l}\text { Neonatology } \\
\text { Unit care }\end{array}$ & Laptop & $\begin{array}{l}\text { Enchanted } \\
\text { forest }\end{array}$ & Neonatology & 5 & 0 & 5 \\
\hline
\end{tabular}




\begin{tabular}{|lllllll|}
\hline $\begin{array}{l}\text { Medicine } \\
\text { Apps }\end{array}$ & $\begin{array}{l}\text { Interface } \\
\text { used }\end{array}$ & $\begin{array}{l}\text { Virtual } \\
\text { scenario }\end{array}$ & Area & Cases & $\begin{array}{l}\text { Control Patients } \\
\text { group }\end{array}$ & participants \\
\hline Colposcopy & Laptop & $\begin{array}{l}\text { Enchanted } \\
\text { forest }\end{array}$ & Ginecology & 20 & 23 & 43 \\
\hline $\begin{array}{l}\text { Upper GI } \\
\text { Endoscopy }\end{array}$ & $\begin{array}{l}\text { Spider HMD } \\
\text { Game }\end{array}$ & Spider game & Endoscopy & 200 & 200 & 400 \\
\hline Colonoscopy & Laptop & $\begin{array}{l}\text { Enchanted } \\
\text { forest }\end{array}$ & Endoscopy & 3 & 0 & 3 \\
\hline $\begin{array}{l}\text { Unit care } \\
\text { TOTAL } \\
\text { PATIENTS }\end{array}$ & Laptop & $\begin{array}{l}\text { Enchanted } \\
\text { forest }\end{array}$ & Cardiac surgery & 20 & 22 & 42 \\
\hline
\end{tabular}

Table 7. Interfaces and VR scenarios used in each group as well as the total patients participants in the groups studied and controls.
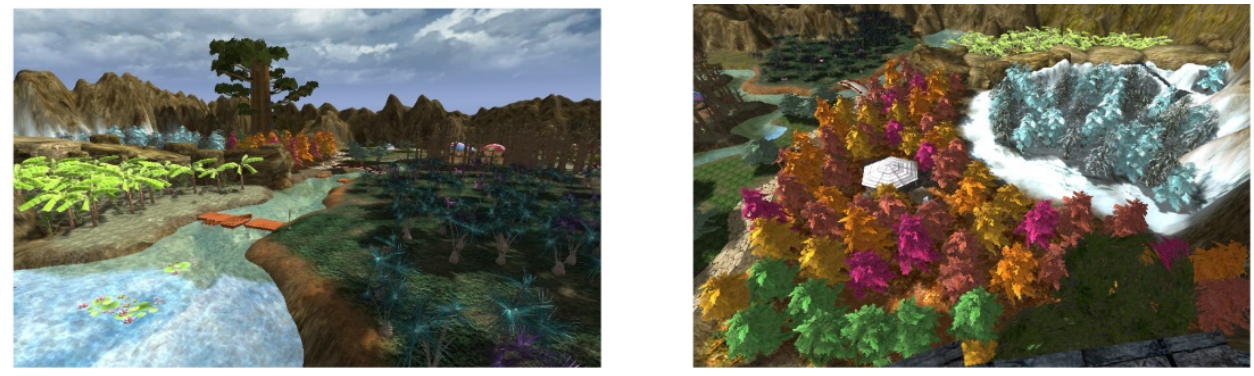

Figure 2. Enchanted forest scenario used in the majority of procedures.
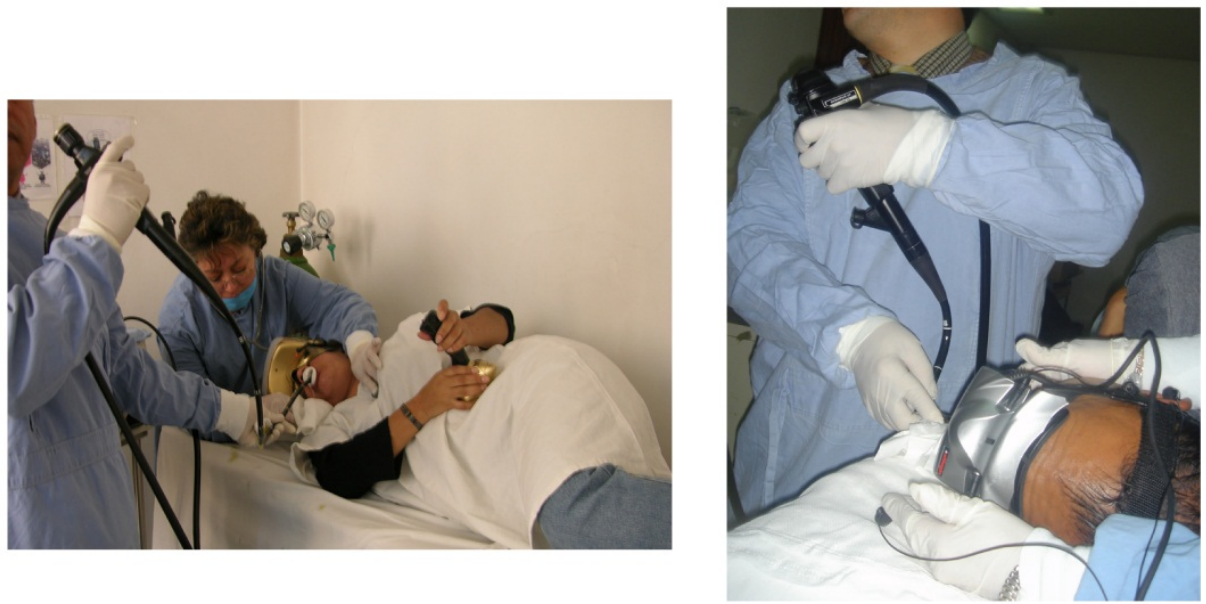

Figure 3. Upper Gastrointestinal Endoscopy. 


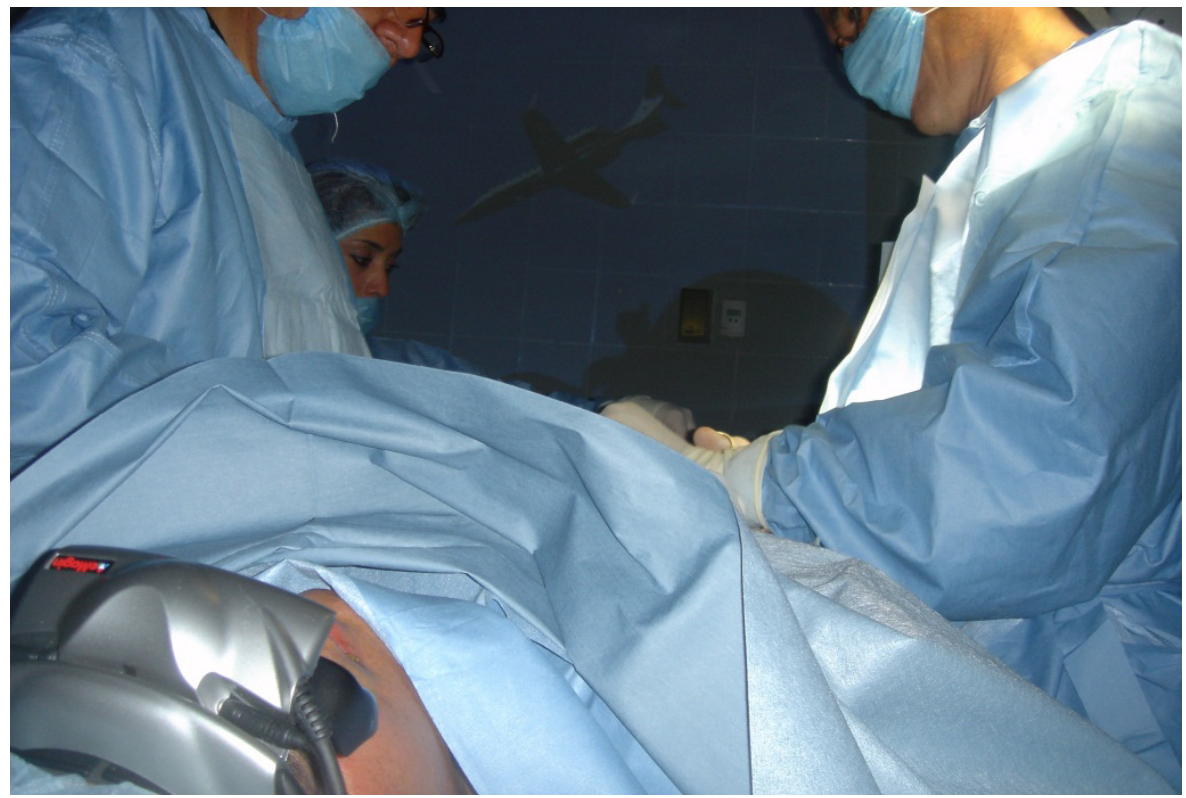

Figure 4. Ambulatory surgery with regional anesthesia

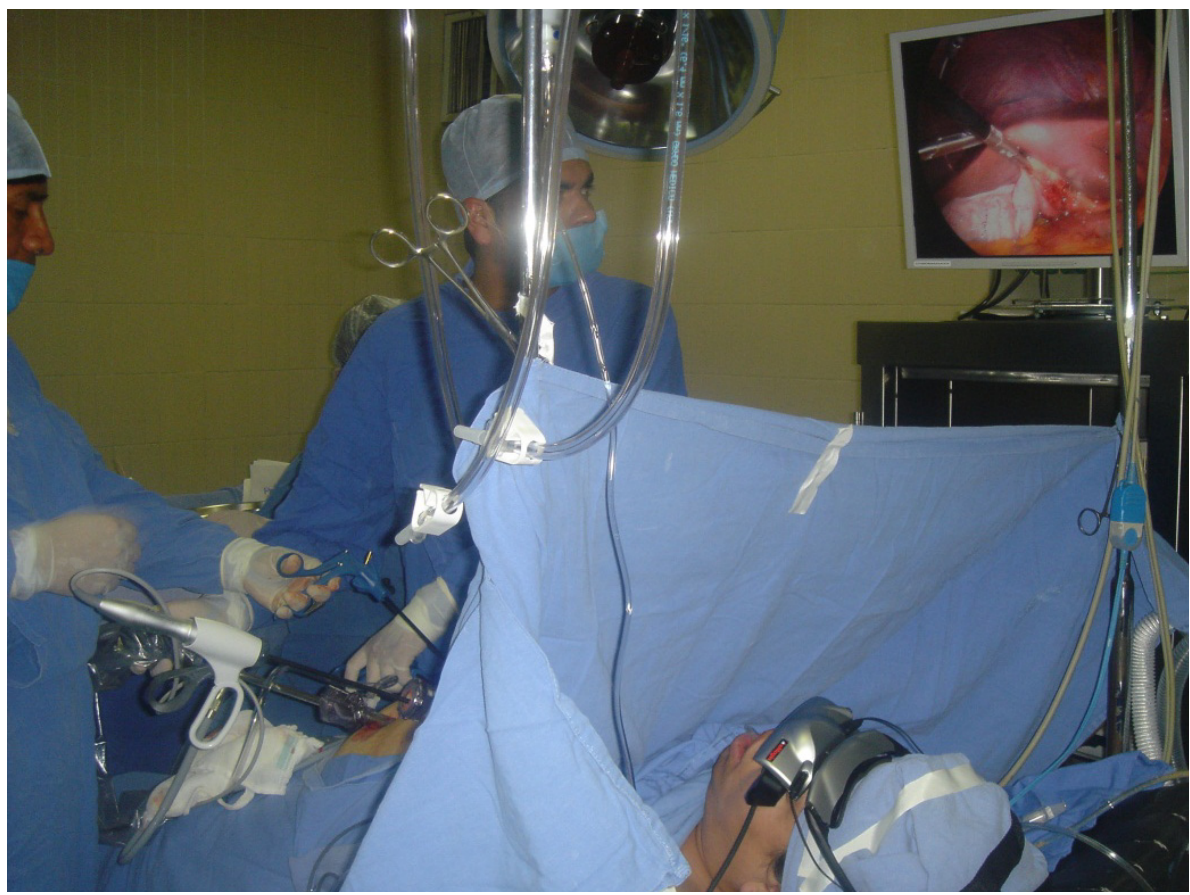

Figure 5. Endoscopic surgery with regional anesthesia 


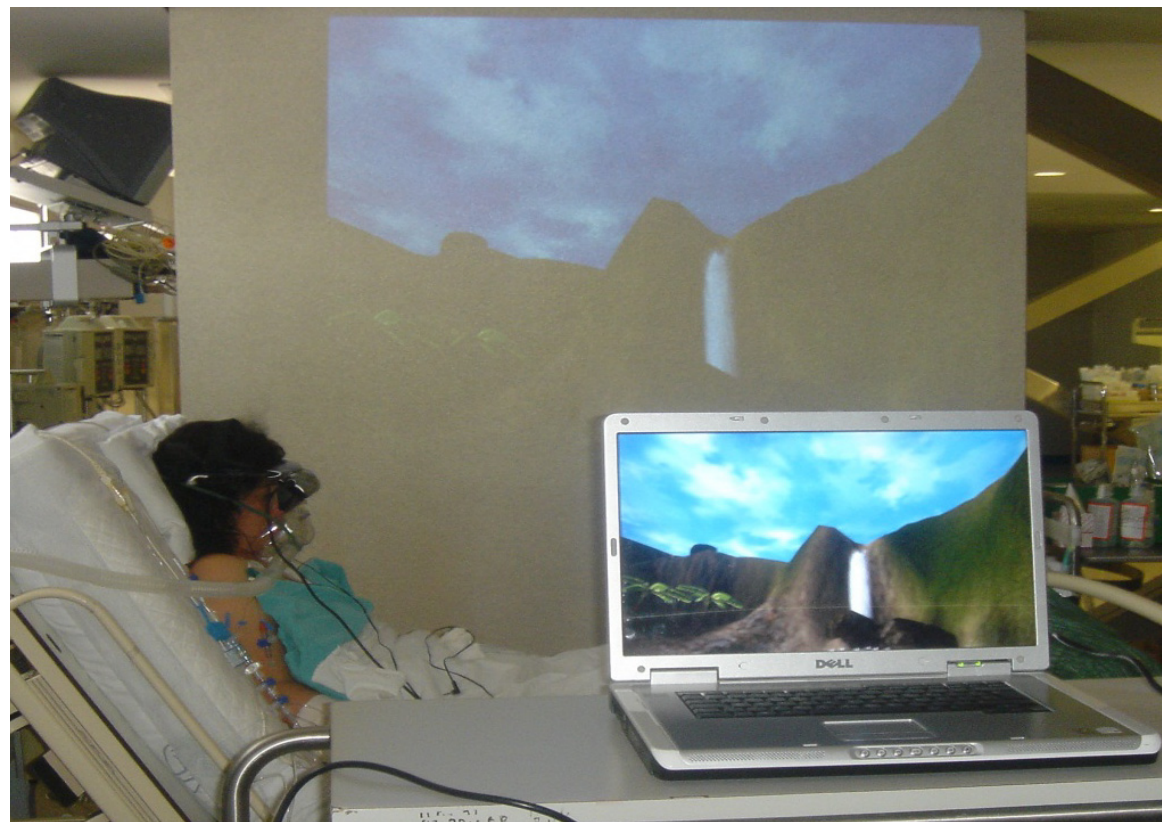

Figure 6. Care unit of cardiac surgery

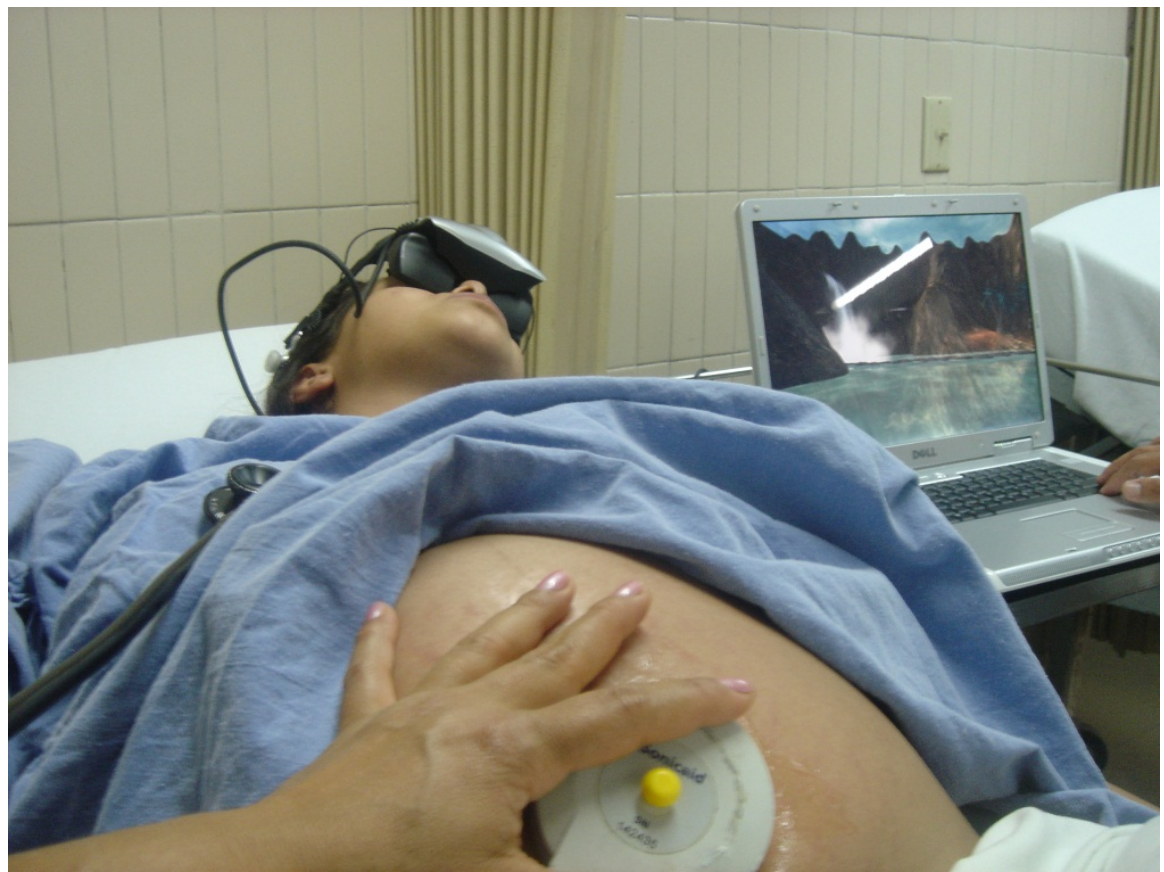

Figure 7. Labor room 


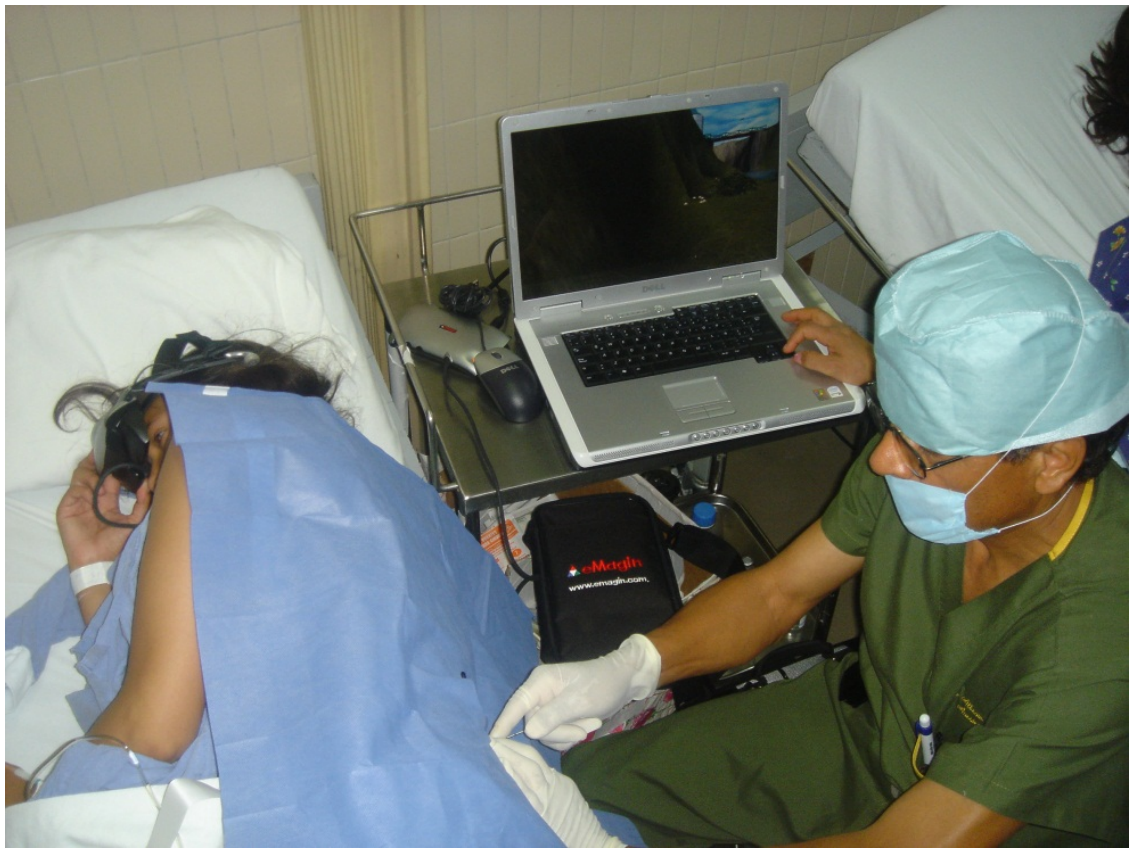

Figure 8. Anesthesia. Epidural/ spinal block

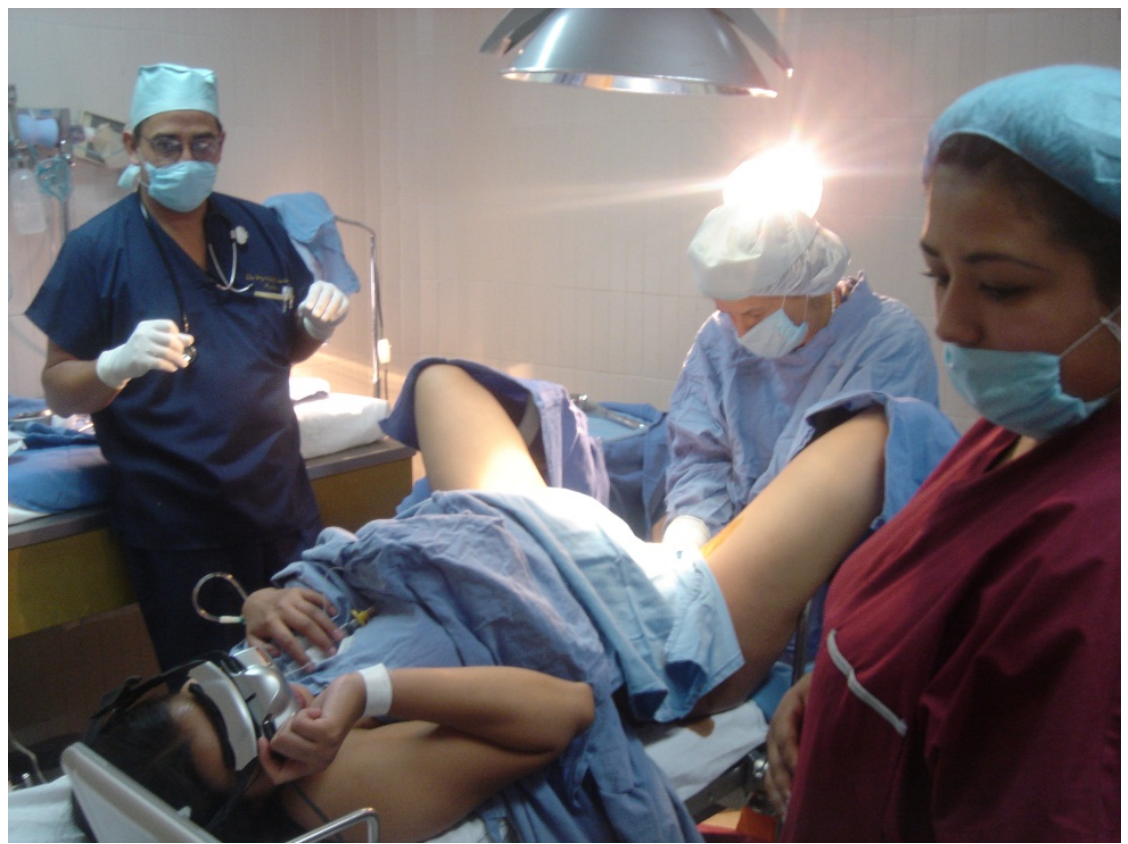

Figure 9. Delivery room 


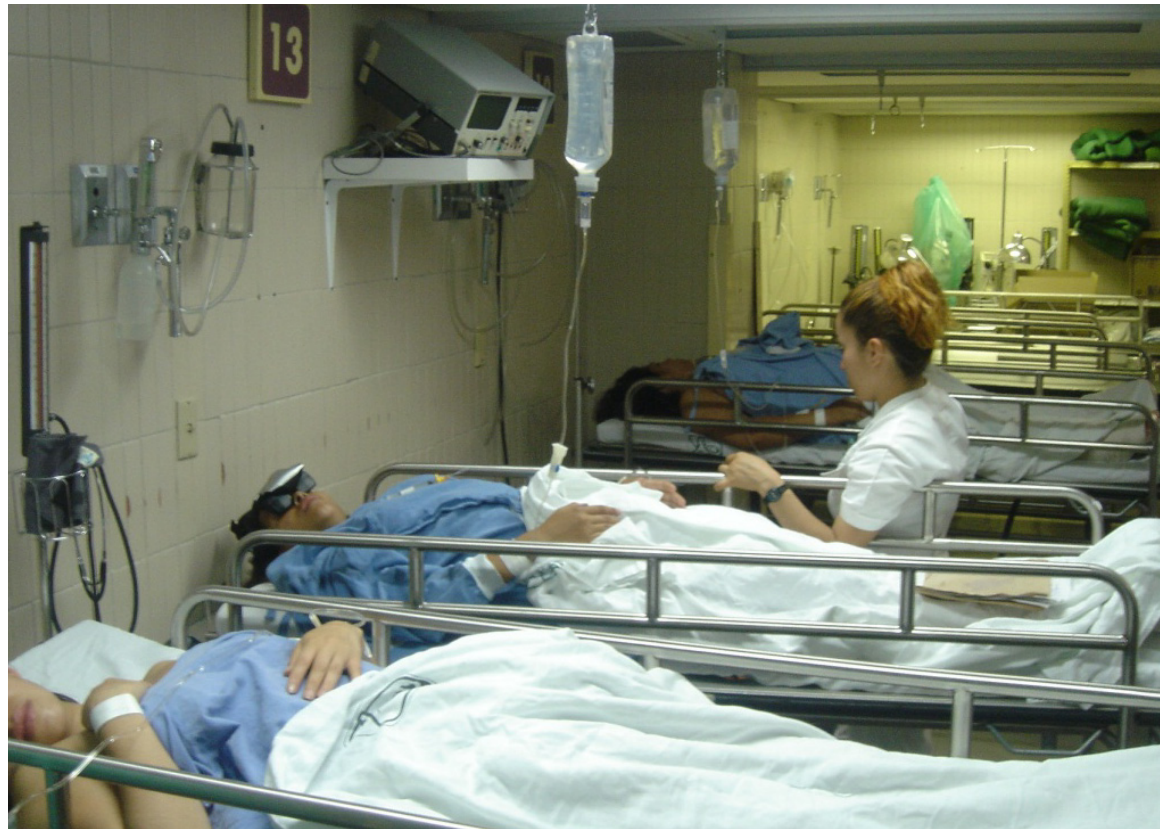

Figure 10. Recovery room. Post cesarean surgery

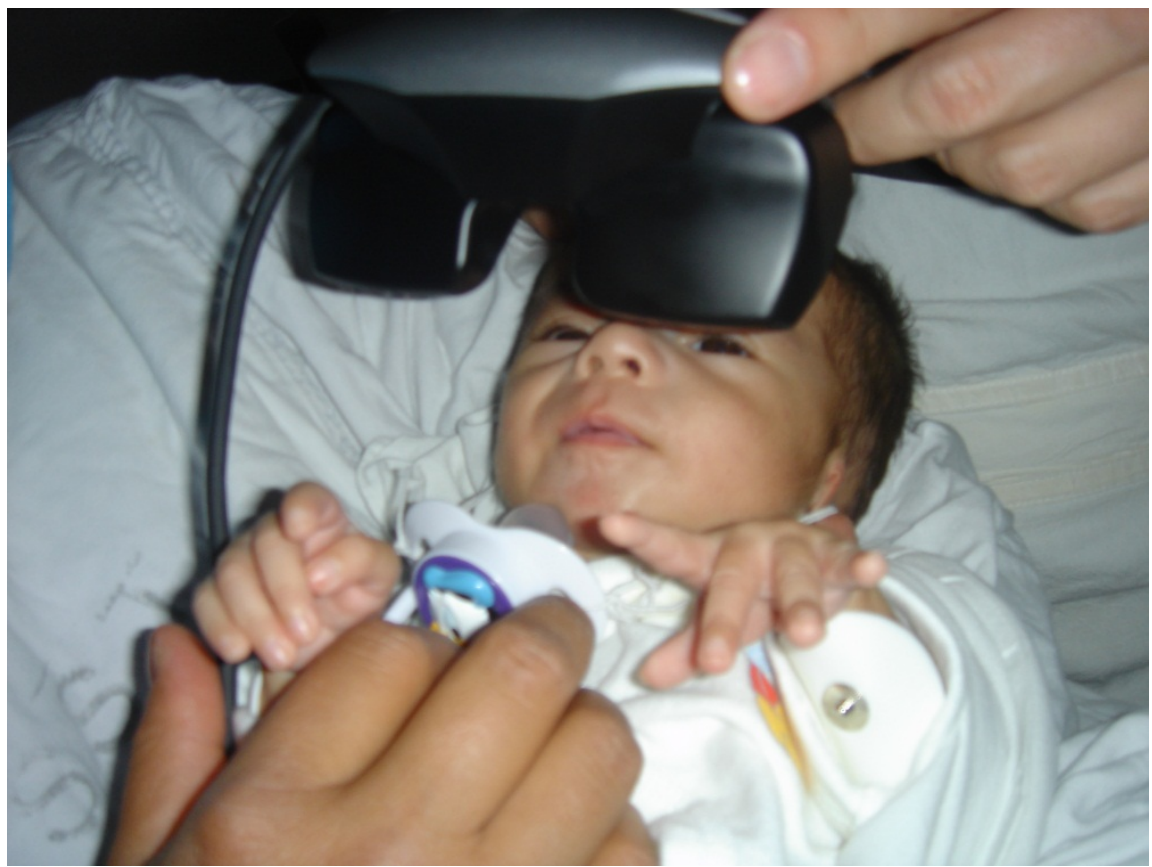

Figure 11. Neonatology care unit 

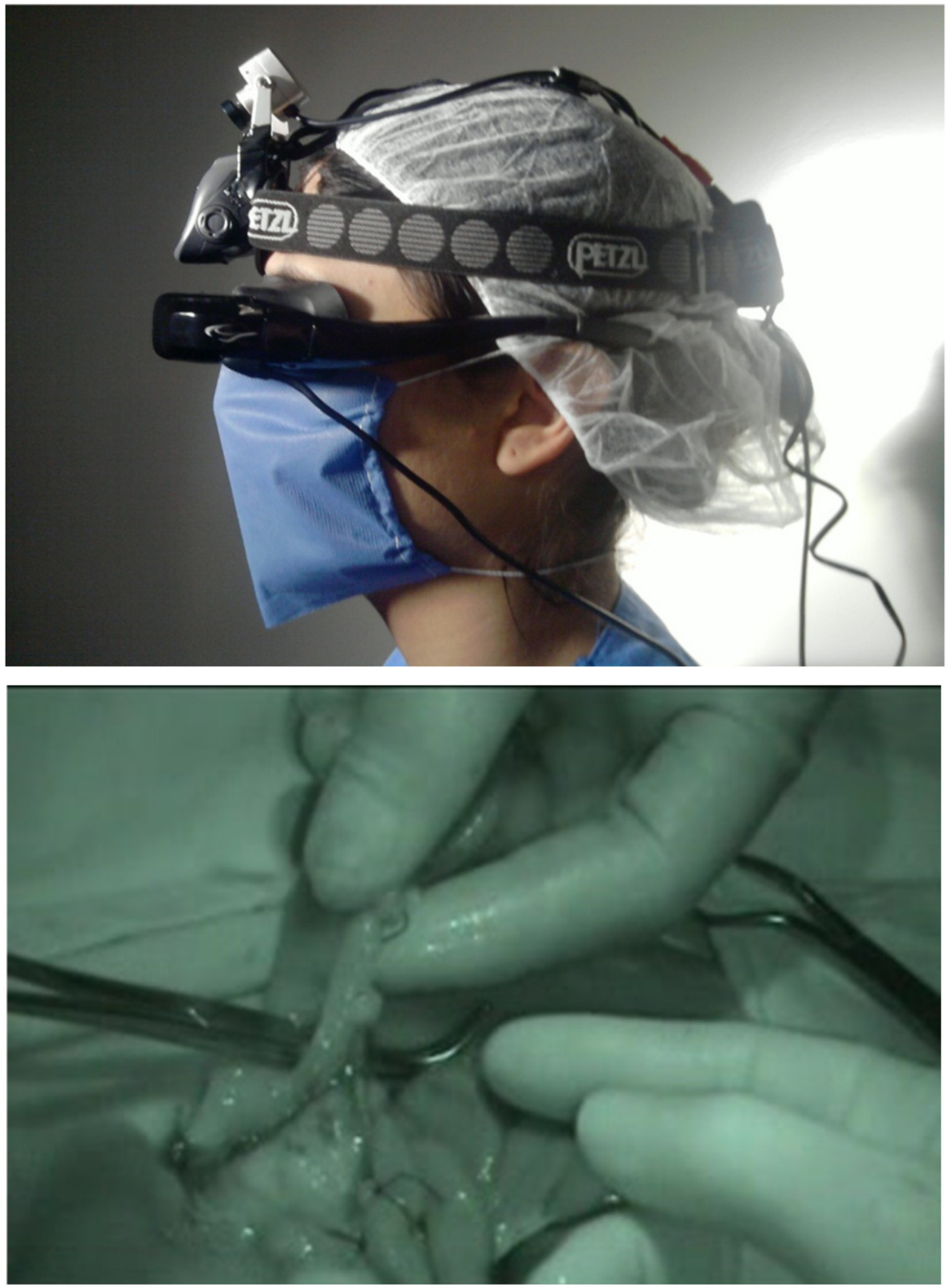

Figure 12. Night vision equipment (above). Appendectomy with night vision goggles. School of Medicine, Universidad Panamericana (Below) 


\section{Author details}

José Luis Mosso

School of Medicine, Universidad Panamericana, Mexico

Regional Hospital No. 25 of the Instituto Mexicano del Seguro Social, IMSS, Mexico

Clínica Alberto Pisanty Ovadía ISSSTE, Mexico

Brenda Wiederhold and Mark Wiederhold

Virtual Reality Medical Center President, Interactive Media Institute, Mexico

Gregorio T. Obrador

School of Medicine Director, Universidad Panamericana, México

Verónica Lara

Centro Médico Nacional 20 de Noviembre ISSSTE, Hospital de Ginecología y Obstetricia Luis

Castelazo Ayala No. 4, IMSS, Mexico

Amador Santander

UMAE, Centro Médico Nacional la Raza, IMSS, Mexico

\section{References}

[1] Rizzo, A.A. (1994). Virtual Reality applications for the cognitive rehabilitation of Persons with traumatic head injuries. In Murphy, H.J. (ed.), Proceedings of the 2nd International Conference on Virtual Reality and Persons With Disabilities. CSUN: Northridge.

[2] Schneider, S.M., Workman, M.L., Effects of Virtual Reality on symptom distress in children receiving chemotherapy. CyberPsychology and Behavior, 1999. 2(2): p. 125-134.

[3] Hoffman, H.G., Patterson, D.R., Carrougher, G.J, Use of Virtual Reality for Adjunctive Treatment of Adult Burn Pain During Physical Therapy. 2000.

[4] Hoffman, H.G., Doctor, J.N., Patterson, D.R., et al., Virtual reality as an adjunctive pain control during burn wound care in adolescent patients. Pain, 2000. 85(1-2): p. 305-309.

[5] Hoffman, H.G., Patterson, D.R., Carrougher, G.J., Use of Virtual Reality for adjunctive treatment of adult burn pain during physical therapy: A controlled study. The Clinical Journal of Pain, 2000. 16(3): p. 244-250. [11] Schneider, S.M., Workman, M.L., Effects of Virtual Reality on symptom distress in children receiving chemotherapy. CyberPsychology and Behavior, 1999. 2(2): p. 125-134.

[6] Schneider, S.M., Ellis, M., Coombs, W.T., et al., Virtual Reality Intervention for Older Women with Breast Cancer. CyberPsychology and Behavior, 2003. 6(3): p. 301-307.

[7] Sander W, Eshelman D, Steele J, Guzzetta CE. Effects of distraction using virtual reality glasses during lumbar punctures in adolescents with cancer. Oncol Nurs Forum 2002;29:E8-15.

[8] Reger GM. Effectiveness of virtual reality for attentional control to reduce children's pain during venipuncture. Paper presented at Piscataway NJ:Proceedings of the 2nd International Workshop in Virtual Rehabilitation, 62-67, 2003. 
[9] Mark D. Wiederhold, MD, PhD, FACP, and Brenda K. Wiederhold, PhD, MBA, BCIA. Virtual Reality and Interactive Simulation for Pain Distraction. Pain Medicine. Volume 8, number S3. 2007 p.p. S182-S188.

[10] Brenda K. Wiederhold and Mark D. Wiederhold. Managing Pain in Military Populations with Virtual Reality.

[11] Wiederhold, M.D., \& Wiederhold B.K. (2010). Virtual Reality and Interactive Simulation for Pain Distraction. CyberTherapy \& Rehabilitation, 3(1), 14-19.

[12] Schneider, S.M. Virtual Reality for the treatment of Breast Cancer. in CyberTherapy. 2003. San Diego, CA: Interactive Media Institute.

[13] Hoffman, H.G., Garcia-Palacios, A., Patterson, D.R., et al., The effectiveness of Virtual Reality for dental pain control: A case study. CyberPsychology and Behavior, 2001. 4(4): p. 527-535.

[14] Tse, M.M.Y., Ng, J.K.F., and Chung, J.W.Y. Visual stimulation as pain relief for Hong Kong Chinese patients with leg ulcers. in CyberTherapy. 2003. San Diego, CA: Interactive Media Institute.

[15] Maani C.V., Hoffman H.G., Morrow M., Maiers A., Gaylord K., McGhee L.L., DeSocio P.A. Virtual Reality pain control during burn wound debridement of combat-related burn injuries using robot-like arm mounted VR goggles. J Trauma, 2011. 71(1 Suppl): S125-30.

[16] Mosso J.L., Gorini A., De La Cerda G., Obrador T., Almazan A., Mosso D., Nieto J.J., Riva G. Virtual reality on mobile phones to reduce anxiety in outpatient surgery. Stud Health Technol Inform, 2009. 142: 195-200.

[17] Mosso, J.L., Rizzo S., Wiederhold B., Lara V., Flores J., Espiritusanto E., Minor A., Santander A., Avila O., Balice O., Benavides B. Cybertherapy-new applications for discomfort reductions. Surgical care unit of heart, neonatology care unit, transplant kidney care unit, delivery room-cesarean surgery and ambulatory surgery, 27 case reports. Stud Health Technol Inform, 2007. 125:334-6. 